recommends that a general report be prepared on the social organization and general culture of the ethnic groups; and that this be supplemented by more intensive studies of a series of village communities, special attention being given to the status and role of the headmen, the actual and potential functions of wards, age-sets and other institutions, and the external relations of the villages. Where experiments seeking to improve and diversify production are being undertaken, the indigenous economic organization should also be investigated in the course of these intensive studies. Professor Forde also recommends a social survey of Bathurst, the capital, because (among other reasons) of the tensions that are developing between the Aku (descendants of foreign immigrants, including released slaves, who have adopted Western standards) and the urbanized Wolof who now form the largest element in the permanent population. Finally, Professor Forde offers suggestions of the ways in which these investigations could be carried out.

\title{
A Seven-year Plan of Research
}

Dr. Max Gluckman has now issued the plan of research that is to be undertaken by the Rhodes-Livingstone Institute in British Central Africa, that is to say, in Northern and Southern Rhodesia and Nyasaland. The planning has been made possible by grants amounting to $f, 21,200$ from the Development and Welfare Fund to support three sociologists and one economist (a further $£ 5,200$ has been applied for to cover the cost of another sociologist), the Beit Research Fellowship of $£ 1,250$ per annum for work in Southern Rhodesia, grants from the Northern Rhodesia Government $(£ 1,500$ per annum plus certain services) and grants from other governments and bodies. The plan has been approved by the Trustees and by the Governments concerned. Dr. Gluckman proudly claims that the RhodesLivingstone Institute is the first social research Institute in the British colonies to be ready to expand its work. His elaborate scheme merits, and will receive, the closest study by social anthropologists.

The plan is based upon the concept that industrialization with labour migration dominates the whole trend of social development in Africa. Other problems there are, but all these must be studied within the embrace of this dominant one. This conception points naturally to two foci of research: (1) the mining and non-mining urban areas; and (2) the rural areas from which labour migrates. The latter are of different kinds and present diverse phases of the problem: (a) Areas situated far from labour centres, which export labour, are without cash-crops and have little or no internal trade (e.g. Bembaland); (b) rural areas where saleable crops are grown, far from the railway but adjacent to European farms where work can be obtained as well as in industrial centres, with more trade than in Bembaland, and exporting labour (e.g. Angoniland); (c) rural areas exporting labour, with no adjacent farms, but with some export of fish and possibly cattle, and a highly developed system of internal trade (Barotseland); (d) rural areas growing cash-crops, with some fish trade, little internal trade, exporting comparatively little labour (e.g. Tongaland); (e) rural areas with largescale fishing industry for export, with internal trade, exporting comparatively little labour (e.g. the Luapula valley); $(f)$ European farming areas far from the line and on the line. Among the many subjects that will be studied in such sample areas, urban and rural, are the following: the differential effects of labour migration and urbanization on the family and kinship organization, the economic life, the political values, the religious and magical beliefs of the peoples; the drift of population from Angola and Mozambique into some of these areas whence it goes on in part into the towns; the formation of new groups and relationships in both urban and rural areas. (Dr. Gluckman emphasizes that he does not view the social processes at work as entirely disintegrative.)

Within the framework thus sketched the team of researchers will make a number of supplementary studies, e.g. on the sociological and psychological bases of witcheraft and 
modern developments in this type of thought. Dr. Gluckman is well aware that when his sample areas are selected the field will be far from covered geographically: there will be gaps. These he will fill when men and money are forthcoming. He hopes, for example, that it will be possible to make a study of the Ila people, partly to supplement the work of Smith and Dale which (as he truly says) "was weak on economics, land tenure and social organization', and for special reasons, namely: they are said to be dying out and it is essential to combine sociological and demographical studies of them with any medical survey that may be made, to gauge the correctness of this assumption; the Ila are a true cattle people, unlike the Lozi, and their whole adaptation to the Kafue flats should be compared with the Lozi adaptation to the Barotse plain; they are apparently an intrusion of an East African cattle-complex people in the midst of tribes coming from the CongoAngola regions; the result of this survey would provide comparative data on the 'progressive 'Tonga, their neighbours, for the Ila are said to be very 'conservative'.

Each research-worker will be expected on his first tour to make a general survey of the modern culture of the area assigned to him. At the request of the Government they will give special attention to land tenure. On their second visit they will concentrate on the significant problem which we have outlined. Dr. Gluckman gives a brief indication of 'the writing programme' which comprises both studies of each area and comparative studies, all culminating in a general survey of the economic and social organization of Northern Rhodesia, supplemented, he hopes, by demographic, psychological and other analyses. The whole research is to be the work of a team. The trained sociologist will work hand in glove with an economist; and these with agriculturists, psychologists, medical officers, educationists and lawyers. The Institute is independent of Government but it will have the co-operation of the technical government departments.

It seemed to us at one time that the Institute was about to commit the cardinal error of divorcing linguistic from sociological research. The plan says little about language. "We are prepared to assist where we can' in solving linguistic problems, says Dr. Gluckman; but the evident intention is to leave these to the Education Department while recognizing that mutual help between sociologist and linguist is essential.

Only one paragraph of the Plan is given to Nyasaland and little is said in it beyond the statement that a worker will go to the Southern Province; the problems to be studied are similar to those of Northern Rhodesia. The Beit Research Fellow is to study the Shona in a block of reserves east and south of Salisbury. (He is already at work.)

We think that Dr. Gluckman is optimistic if he thinks that all the work he has planned can be carried out in seven years. But we are sure that every reader of Africa will wish him the best success possible. His scheme might well provide a pattern for research elsewhere.

\section{Research in West Africa}

Monsreur T. Monod, Directeur de l'Institut Français d'Afrique Noire, informs us that the ethnologist, M. J. Joire, and a geographer, M. J. Richard-Molard, have recently been appointed to the staff of the Institut and that appointments of a linguist and two other ethnologists will be made shortly. I.F.A.N. is also organizing, in collaboration with the Service de Santé, an investigation in physical anthropology, directed by Médecin-Colonel L. Pales, among the Fula of Fouta Djallon, the Bambara and the Mossi. The study of dietary questions will be included in the investigation.

\section{A Research Institute for the Belgian Congo}

UNE commission provisoire pour l'organisation de la recherche scientifique au Congo Belge s'est constituée. ... Elle préconise la création, au Congo Belge, d'un Institut de recherche 